\title{
Pelatihan Pembuatan Materi Ajar Digital Bagi Tenaga Pendidik Di Masa Pandemi
}

\author{
Rambu Naha, Christa Olivia Geraldine, Chrisindo Reformanda \\ ${ }^{1}$ Program Studi Pendidikan Jarak Jauh Ilmu Komunikasi \\ Universitas Pelita Harapan \\ ${ }^{2}$ Program Studi Pendidikan Jarak Jauh Ilmu Komunikasi \\ Universitas Pelita Harapan \\ ${ }^{3}$ Program Studi Pendidikan Jarak Jauh Ilmu Komunikasi \\ Universitas Pelita Harapan
}

Rambu.naha@uph.edu, christa.geraldine@uph.edu, chrisindo.reformanda@uph.edu

\begin{abstract}
Abstrak
Pembatasan sosial berskala besar selama pandemi CoVID-19 menyebabkan proses belajar-mengajar tidak lagi memungkinkan untuk diadakan secara tatap muka. Proses belajar-mengajar dalam ruang kelas fisik harus beralih ke ruang kelas virtual. Dalam banyak kasus, tenaga pendidik cenderung tidak siap menghadapi perubahan yang sangat cepat ini karena minimnya keterampilan dan wawasan mengenai sistem pembelajaran daring, khususnya keterampilan dalam pembuatan materi ajar digital dan pemahaman untuk dapat mengemas materi ajar yang sesuai dengan konteks pembelajaran jarak jauh. Berdasarkan kondisi ini, maka Program Studi Pendidikan Jarak Jauh (PJJ) Ilmu Komunikasi Universitas Pelita Harapan menilai perlu untuk mengadakan pelatihan pembuatan materi ajar digital, sebagai salah satu wujud pengabdian kepada masyarakat. Kegiatan ini bertujuan untuk memperlengkapi tenaga pendidik di seluruh Indonesia untuk dapat memanfaatkan teknologi sehingga mampu menghasilkan materi pembelajaran digital yang dapat diakses kapan dan dari mana saja. Pelaksanaan kegiatan ini dilakukan secara daring dengan menyebarkan kuesioner sebelum pelaksanaan kegiatan, untuk mengetahui sejauh mana pemahaman peserta terhadap pembuatan materi ajar digital, serta dapat menjadi landasan dalam membuat materi pelatihan. Hasil pelaksanaan pelatihan ini menunjukkan bahwa 99\% peserta (tersebar di hampir seluruh wilayah Indonesia) dapat memahami materi yang diberikan dan materi ajar digital dapat digunakan sebagai salah satu model pembelajaran daring khususnya di masa pandemi covid.
\end{abstract}

Kata Kunci: pendidikan jarak jauh, teknologi edukasi, materi ajar digital

\section{PENDAHULUAN}

Pandemi CoVID-19 mengubah banyak sisi dalam kebiasaan hidup manusia. Virus ini pertama kali dilaporkan terjadi di kota Wuhan pada akhir tahun 2019 dan dengan cepat menyebar ke berbagai penjuru dunia termasuk di Indonesia. Kasus CoVID-19 pertama di Indonesia diumumkan pada 2 Maret 2020, dengan 2 orang pasien positif yang berasal dari kota Depok (Nuraini, 2020). Semenjak kasus pertama, jumlah pasien positif di Indonesia terus bertambah sehingga pemerintah harus mewajibkan masyarakat untuk mengikuti protokol kesehatan yang ditetapkan WHO, yakni physical distancing, termasuk menerapkan kebiasaan menggunakan masker, mencuci tangan dan pola hidup sehat, serta di beberapa wilayah dengan episentrum penyebaran tertinggi, juga diberlakukan

$$
\text { Pendidikan }
$$


Pembatasan Sosial Berskala Besar (PSBB). Protokol kesehatan untuk memerangi penyebaran CoVID-19 ini kemudian mengharuskan setiap aktivitas sosial yang memungkinkan adanya kontak fisik untuk dibatasi, serta masyarakat didorong untuk melakukan aktivitas sehari-hari di dalam tempat tinggal mereka dengan himbauan "di rumah aja". Pembatasan interaksi yang terjadi di ruang publik merupakan salah satu kunci untuk mengurangi penyebaran virus ini (Rosés, et al.). Perkantoran, sektor industri, jasa, termasuk juga pendidikan, banyak yang membatasi terjadinya interaksi secara langsung; bahkan hampir semua aktivitas dilakukan dari rumah saja.

Kondisi pandemi tidak boleh menjadi penghalang bagi terlaksananya proses pendidikan, karena setiap orang berhak untuk memperoleh pendidikan (Undang-Undang Republik Indonesia Nomor 39 tentang Hak Asasi Manusia 1999). Oleh karena itu, tenaga pengajar perlu untuk tetap dapat memfasilitasi terjadinya proses belajar yang optimal. Hal ini tentu tidak mudah dilakukan di tengah perubahan yang begitu cepat akibat pandemi CoVID-19, karena umumnya tenaga pengajar yang terbiasa dengan pengadaan kelas secara tatap muka belum memiliki pengalaman ataupun keterampilan yang cukup untuk melakukan pengajaran secara daring, sedangkan pengajaran daring merupakan solusi utama yang mau tidak mau harus dipilih di tengah situasi ini.

Jika ditinjau dari segi infrastruktur, pembelajaran daring dapat dilakukan secara maksimal dengan didukung oleh adanya akses internet yang stabil, khususnya pada saat proses belajar tatap muka harus dilakukan secara real-time yang termediasi oleh teknologi panggilan video, seperti melalui penggunaan Zoom, Google Meet, Skype for Business, atau program sejenis lainnya. Sayangnya, Indonesia menempati urutan keempat terendah untuk angka kecepatan internet rata-rata, jika dibandingkan 46 negara lain di dunia (We are social, 2020). Kualitas akses internet yang tidak stabil yang dialami baik oleh tenaga pengajar maupun peserta didik menjadi kendala tersendiri. Apabila proses belajar harus dilakukan secara realtime di tengah kondisi pandemi, maka peserta didik terpaksa harus kehilangan momentum belajar akibat akses internet yang tidak stabil.
Kondisi tenaga pengajar yang masih belum siap dalam menghadapi perubahan yang terjadi begitu cepat akibat CoVID-19, ditambah dengan kebutuhan yang menuntut para civitas akademika agar mampu beradaptasi dengan modus pembelajaran online, dan upaya dalam melakukan kegiatan belajar mengajar yang terhalang oleh akses internet yang belum merata maupun stabil. Hal ini merupakan kondisi yang harus segera dicari solusinya, agar kegiatan belajar mengajar tetap dapat berjalan di tengah situasi pandemi CoVID-19 saat ini. Oleh karena itu, pembuatan materi ajar digital perlu menjadi pengetahuan awal yang harus dimiliki oleh tenaga pengajar, sehingga mereka dapat mempersiapkan materi ajar yang dapat diakses oleh peserta didik kapan saja dan di mana saja. Dengan adanya materi ajar digital, maka proses belajar mengajar tidak perlu terhalang oleh batasan pengadaan kelas secara real-time, misalnya dengan penggunaan Zoom, Google Meet, Skype for Business dan platform sejenis lainnya, tetapi kapan saja siswa memiliki akses untuk belajar, maka proses belajar mengajar pun dapat terjadi pada saat itu juga. Dengan demikian, materi ajar digital seharusnya menjadikan situasi belajar mengajar menjadi lebih efektif dan menyenangkan (BAŞARMAK, 2019). Materi ajar dalam bentuk digital juga membantu tenaga pengajar untuk dapat menghasilkan materi yang singkat dan padat, namun tetap dapat mencapai tujuan pembelajaran yang telah ditetapkan sebelumnya. Dalam hal ini, teknologi yang digunakan dalam proses pembelajaran bukanlah sebuah tujuan akhir, tetapi alat yang digunakan untuk mencapai tujuan (Demirkan, 2019).

Di tengah situasi pandemi ini, tentu saja pembuatan materi ajar digital harus dapat dilakukan dari rumah dengan memanfaatkan sumber daya yang dimiliki. Materi ajar digital (digital teaching materials) dilakukan dalam bentuk audiovisual untuk menyampaikan informasi dengan format digital (Yang, Weng, Yang, \& Wu, 2014). Untuk menghasilkan materi ajar digital dengan standar video dan editing yang menarik tentu bukan hal yang mudah bagi tenaga pengajar yang umumnya belum pernah membuat sendiri materi ajar digital.

$$
\text { Pendidikan }
$$


Umumnya, pembuatan materi ajar digital perlu bantuan dari editor video dengan teknologi editing yang cukup rumit. Dalam kondisi yang serba terbatas dan juga mendesak ini, tenaga pendidik perlu menghasilkan materi ajar digital tetapi dengan cara yang mudah dan praktis. Untuk itu, setiap solusi yang ditawarkan perlu untuk menyesuaikan dengan sumber daya yang dimiliki oleh tenaga pendidik serta dapat dilakukan dari rumah, namun tetap dapat menghasilkan materi ajar digital yang menjangkau seluruh peserta didik.

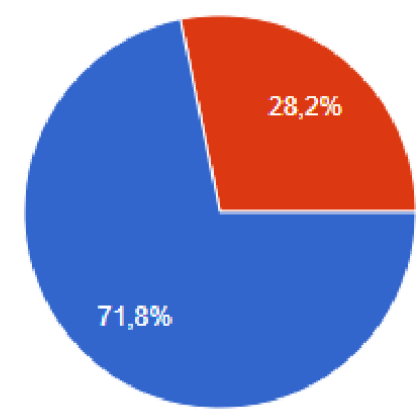

Gambar 1. Presentasi Peserta yang telah memiliki power point office 365

Pembuatan materi ajar digital ini dilakukan dengan memanfaatkan Powerpoint Office 365 yang mampu merekam audio dan visual secara bersamaan dengan materi yang akan dijelaskan dalam bentuk presentasi berformat .ppt yang sudah disiapkan sebelumnya. Sebanyak $71,8 \%$ dari 411 peserta telah memiliki Powerpoint Office 365 yang telah terinstal di laptop mereka (Gambar 1). Dengan memanfaatkan aplikasi ini, siswa dapat melihat bagaimana para pengajar menjelaskan setiap materi secara audio-visual.

\section{METODE}

Untuk dapat memberikan solusi atas permasalahan yang dialami tenaga pengajar di tengah pandemi CoVID-19 ini, berikut adalah langkah-langkah yang dilakukan:
1. Menyebarkan kuesioner pra-workshop untuk mengetahui profil dan kesiapan peserta dalam menerima materi

2. Menyiapkan materi sesuai dengan kebutuhan peserta

3. Pelaksanaan Webinar

a. Menjelaskan kondisi serta peluang pembuatan materi ajar digital di tengah pandemi CoVID-19

b. Menjelaskan langkah-langkah pembuatan desain Powerpoint yang menarik

c. Menjelaskan langkah-langkah pembuatan materi ajar digital menggunakan Powerpoint Office 365

d. Memberikan kesempatan bagi para peserta untuk melakukan praktik secara langsung untuk setiap tahapan pembuatan materi ajar digital

e. Sesi diskusi dan tanya jawab

f. Pemberian E-Document Panduan Pembuatan Materi Ajar Digital sehingga para peserta dapat mempelajari secara mandiri di rumah masing-masing

Persiapan pelatihan pembuatan materi ajar bagi tenaga pengajar membutuhkan waktu kurang lebih 2 minggu. Tim persiapan dibagi dalam beberapa fungsi, di antaranya: 1) Tim teknis, yang mengatur pelaksanaan webinar terkait dengan isu teknis pengaturan platform video conference; 2) Tim registrasi, yang bertugas untuk mengumpulkan data seluruh peserta dan korespondensi dengan peserta baik melalui email, SMS maupun WhatsApp untuk menyampaikan tautan (meeting ID dan Password) video conference, maupun menjawab pertanyaan-pertanyaan seputar administrasi pendaftaran; 3) Tim publikasi dan administrasi, bertugas dalam pembuatan design materi publikasi dan melakukan rekap jumlah peserta, serta mengirimkan sertifikat dan materi pemakalah kepada para peserta.

Pelatihan pembuatan materi ajar digital dilaksanakan melalui aplikasi Zoom Meeting. Ruang meeting Zoom dibuka pada pukul 09.45 10.00 WIB untuk registrasi ulang sebelum acara dimulai. Kemudian kegiatan dibuka oleh host untuk membaca tata tertib selama kegiatan berlangsung

$$
\text { Pendidikan }
$$


serta membagikan kuesioner pra-workshop. Setelah mengisi kuesioner pra-workshop, host memperkenalkan profil pemateri dalam pelatihan ini. Adapun materi yang disampaikan dalam pelatihan secara garis besar membahas prinsip utama dalam kelas daring dan implementasi serta praktik pembuatan materi ajar digital. Setelah selesai memberikan materi, host meminta para peserta webinar mengisi kuesioner yang sudah dibuat oleh panitia. Sebanyak 20 pertanyaan diskusi yang diajukan peserta setelah sesi materi berakhir. Selain itu, sepanjang kegiatan berlangsung partisipasi peserta terangkum dalam transkrip 14 halaman chat sebagai bentuk komunikasi dengan pemateri. Di akhir acara tim administrasi mendata setiap peserta yang mengikuti pelatihan sampai akhir acara, untuk dikirimkan sertifikat elektronik.

\section{HASIL DAN PEMBAHASAN}

\section{Materi Ajar Digital dan Solusi Pembelajaran Daring di Indonesia}

Perubahan yang serba cepat terjadi di masa pandemi, menuntut para pengajar untuk juga dapat cepat beradaptasi dengan pola pembelajaran daring. Materi ajar digital merupakan model pembelajaran daring yang cukup penting (Fang, Chang, Tsai, \& Jen-Lee, 2010). Dengan adanya materi ajar digital, maka membantu tenaga pengajar maupun peserta didik untuk dapat mengikuti proses belajar mengajar secara lebih fleksibel atau dengan kata lain tanpa batasan ruang dan waktu (Yang, Weng, Yang, \& Wu, 2014). Hal ini dapat menjadi sebuah solusi di tengah kualitas akses internet yang masih belum memadai, sehingga baik pengajar maupun peserta didik tidak perlu harus melakukan proses belajar mengajar secara synchronous. Materi ajar digital juga membantu tenaga pengajar untuk dapat merancang dan mempersiapkan materi yang praktis dan fokus untuk mencapai tujuan pembelajaran dalam setiap sesi yang diberikan.

Berdasarkan diskusi yang terjadi pada saat sesi pelatihan, terdapat hal-hal penting yang dapat dijadikan catatan terkait dengan pemanfaatan materi ajar digital bagi tenaga pengajar di Indonesia. Hal pertama yang dapat diamati adalah terkait dengan kemudahan dalam pemanfaatan materi ajar digital.
Para peserta memahami bahwa materi ajar digital membantu mereka untuk melakukan proses belajar mengajar secara online di tengah situasi pandemi, khususnya juga dengan pemanfaatan teknologi yang sederhana seperti power point 365. Disamping itu, materi ajar digital dapat mewadahi tenaga pengajar untuk dapat memberikan penjelasan dalam bentuk audio visual terkait materi yang sedang dipelajari dalam setiap sesi. Berikut beberapa kutipan dari interaksi peserta dalam kolom chat di ruang meeting Zoom.

"Sangat bermanfaat untuk penggunaan kelas online seperti sekarang".

"Kalau materi PPT biasanya kita to the point ya, jadi dengan video ini kita akan menjelaskan lebih lanjut."

Hal kedua yang dapat diamati dalam pelatihan adalah terkait dengan kendala yang dialami tenaga pengajar di Indonesia untuk dapat memanfaatkan materi ajar digital secara maksimal dalam proses pembelajaran online. Kendala yang banyak menjadi perhatian adalah mengenai kesiapan peserta didik, di mana para peserta didik masih belum memiliki perangkat digital yang memungkinkan mereka untuk mengakses materi belajar. Teknologi merupakan hal mendasar bagi tercapainya proses pembelajaran online yang maksimal. Apabila hal ini tidak terpenuhi, maka tidak akan mungkin proses belajar mengajar daring dapat dilakukan. Selain kesiapan peserta didik dalam hal ketersediaan teknologi, hal lain yang menjadi kendala dan perlu untuk mendapatkan perhatian adalah kualitas internet. Para pengajar yang mengikuti pelatihan ini tentu saja merupakan pengajar yang berasal dari daerah atau wilayah yang sudah terhubung dengan akses internet, tetapi beberapa dengan kondisi di mana kualitas kecepatan yang belum maksimal. Di sisi lain, untuk dapat materi ajar digital dalam bentuk audio visual yang dihasilkan umumnya memiliki kapasitas penyimpanan yang cukup besar. Untuk dapat mengunggah materi ajar digital dengan kapasitas yang besar ke berbagai platform pembelajaran online tentu membutuhkan akses internet yang cepat dan stabil, hal ini menjadi tantangan tersendiri bagi para tenaga pengajar. Pemanfaatan online video

$$
\text { Pendidikan }
$$


compressor memang dapat menjadi solusi tetapi harus bernegosiasi dengan kualitas video materi ajar digital itu sendiri.

Pemanfaatan materi ajar digital dalam proses pembelajaran daring di Indonesia sangat membutuhkan kesiapan dari setiap elemen yang terlibat, mulai dari peserta didik, tenaga pengajar dan pemerintah dalam pemanfaatan teknologi juga kualitas akses internet, sehingga proses belajar mengajar daring dapat berlajan dengan maksimal.

Materi ajar digital tentu bukan satu-satunya hal yang perlu dipahami oleh tenaga pengajar dalam proses pembelajaran daring, pelatihan-pelatihan lanjutan terkait perancangan silabus daring, manajemen kelas daring, assessment online, gamification, etika pembelajaran daring, menjadi topik-topik yang perlu dilakukan pada sesi pelatihan berikutnya. Dengan menyasar target peserta yang sama, maka pelatihan lanjutan ini dapat memberikan gambaran yang utuh mengenai hal-hal yang harus dipersiapkan oleh tenaga pengajar dalam proses belajar daring

\section{Pelatihan Daring dan Kualitas Pemahaman Materi}

Pelatihan pembuatan materi ajar digital menjadi sebuah urgensi yang perlu dilakukan, mengingat ketidaksiapan para tenaga pengajar untuk beralih pada pola pengajaran berbasis daring. Pelatihan ini dilakukan secara daring dengan penyebaran peserta yang berasal dari berbagai daerah yang ada di Indonesia mulai dari Papua, Kalimantan, Lampung, Palembang, Kupang, Medan, Ambon, Makassar, Jabodetabek, Yogyakarta, Bandung dan beberapa daerah di Jawa Tengah. Lebih dari $60 \%$ peserta berprofesi sebagai tengaga pengajar mulai dari TK, SD, SMP, SMA/K, serta tenaga administratif sekolah (Gambar 2). Beragamnya latar belakang baik budaya juga profesi dari peserta, serta modus pelatihan berbasis daring (masih jarang dialami oleh peserta) menjadi tantangan tersendiri dalam penyampaian materi yang dapat dipahami dengan baik bagi setiap peserta.

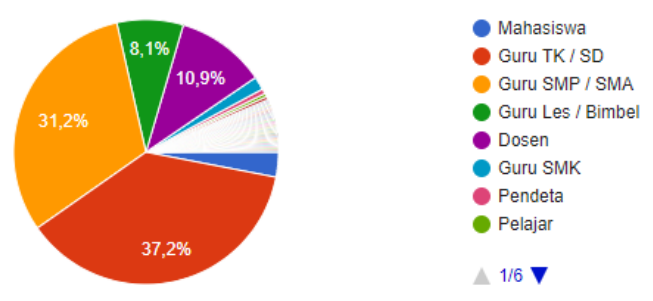

Gambar 2. Profil Peserta Pelatihan

Pelatihan pembuatan materi ajar digital menempatkan peserta sebagai pembelajar baru dalam konteks proses pelatihan secara daring. Untuk dapat menyelenggarakan pelatihan daring yang efektif, maka perlu untuk memahami konsep Multidimensional Learning Task Model (MDLTM). MDLTM dikembangkan untuk pembelajar baru agar berhasil dalam pembelajaran online. Konsep ini menekankan pada 5 aspek yang perlu dinegosiasikan oleh setiap pembelajar yaitu: 1) Teknologi; 2) Learning management system interface; 3) Peran dari pembelajar; 4) Materi belajar; dan 5) Interaksi dalam konteks komunikasi yang termediasi teknologi (Stiller \& Bachmaier, 2017). Pada aspek yang pertama yaitu teknologi, mengacu pada kemampuan peserta untuk dapat menguasai teknologi yang digunakan dalam pelatihan. Aspek yang kedua, yakni learning management system interface, mengacu pada bagaimana pembelajar dapat membangun struktur belajar dalam lingkungan online yang disediakan. Aspek peran pembelajar, berfokus agar para pembelajar dapat menjalankan perannya dengan baik dalam upaya memenuhi capaian dari pelatihan yang diberikan. Aspek keempat, yaitu materi belajar mengacu pada kemampuan pembelajar untuk dapat menguasai materi yang diberikan, dan aspek yang terakhir yaitu interaksi dalam konteks komunikasi termediasi teknologi, berkaitan dengan bagaimana pembelajar dapat memanfaatkan media komunikasi yang ada untuk dapat menguasai materi yang diperoleh (Stiller \& Bachmaier, 2017).

Pelatihan pembuatan materi ajar digital menekankan 3 hal dari konsep MDLTM yaitu teknologi, materi belajar, dan interaksi. Teknologi yang dimanfaatkan dalam pembuatan materi ajar 
digital adalah power point Microsoft 365 yang memiliki tambahan menu slide recording. Powerpoint Microsoft 365 ini dipilih karena kemudahan dalam penggunaannya. Pada aspek materi belajar, maka materi disampaikan secara praktis dan sederhana dengan memberikan handout bagi peserta, sehingga peserta diharapkan dapat secara mandiri menerapkan materi yang sudah diterima dalam pelatihan. Sedangkan pada aspek yang terakhir, yaitu interaksi dalam konteks komunikasi termediasi teknologi, selama praktek peserta diberikan kesempatan untuk berdiskusi secara langsung dengan pemateri terkait dengan kendala yang mereka hadapi pada saat mereka diberikan kesempatan untuk melakukan proses pembuatan materi ajar digital secara mandiri.

Salah satu upaya agar materi yang diberikan dapat dipahami dengan baik yaitu dengan penggunaan bahasa yang sederhana dan menghindari penggunaan istilah yang tidak umum. Seluruh peserta memberikan feedback bahwa pembicara dapat menyampaikan materi dengan bahasa yang mudah dipahami (Gambar 3). Materi pelatihan juga disampaikan dengan kerangka berpikir yang runut mulai dari menjelaskan konteks yang dihadapi tenaga pengajar di masa pandemi, solusi yang ditawarkan berupa pembuatan materi ajar digital, serta menjelaskan detail pembuatan materi ajar digital, dan di akhir sesi peserta diberikan kesempatan untuk secara mandiri membuat materi ajar digital sekaligus berdiskusi dalam tanya jawab. Setiap tahapan pembuatan materi ajar digital yang telah disampaikan, juga diberikan ke peserta dalam bentuk buku panduan.

\section{Pembicara menggunakan bahasa yang mudah dimengerti

\begin{tabular}{lr} 
Setuju & (185) $100 \%$ \\
\hline Tidak Setuju & (0) $0 \%$
\end{tabular}

Gambar 3. Penggunaan Bahasa yang mudah dipahami
Berdasarkan hasil evaluasi pada akhir sesi pelatihan, sebesar $99 \%$ peserta memberikan respons bahwa mereka memahami materi yang disampaikan (Gambar 4). Hal ini menunjukan pola pelatihan yang diberikan berjalan dengan efektif sehingga materi dapat dipahami oleh peserta.

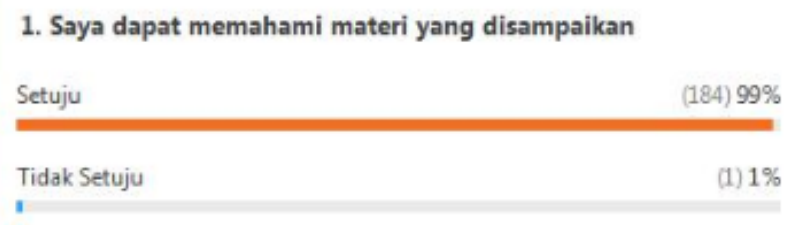

Gambar 4. Pemahaman Materi

\section{KESIMPULAN}

Materi ajar digital dapat menjadi salah satu solusi agar proses pembelajaran secara daring dapat tetap berjalan dengan maksimal. Pemanfaatan materi ajar digital dapat membantu tenaga pengajar maupun peserta belajar untuk dapat tetap menikmati proses belajar mengajar, khususnya disaat sulitnya mengikuti pembelajaran secara synchronous/realtime karena hambatan akses internet.

Sebagai upaya untuk memaksimalkan manfaat dari materi ajar digital bagi proses pembelajaran daring di indonesia, maka diperlukan adanya kesiapan dari setiap elemen atau pihak yang terlibat di dalamnya, mulai dari peserta didik, tenaga pengajar termasuk juga pemerintah. Peserta didik perlu untuk difasilitasi dengan perangkat digital yang memungkinkan untuk dapat mengakses materi belajar, disamping itu tenaga pengajar perlu diperlengkapi dengan keterampilan dalam menghasilkan materi belajar digital yang menjawab tujuan pembelajaran, serta diperlukan dukungan dari pemerintah dalam upaya untuk menyediakan layanan berupa kualitas akses internet yang memadai sampai ke pelosok daerah di Indonesia

Pelatihan pembuatan materi ajar digital yang dilakukan secara daring, dapat dikatakan berhasil karena mempertimbangkan 3 aspek yang perlu dinegosiasikan oleh peserta sebagai pembelajar daring, yaitu teknologi, materi belajar, dan interaksi dalam konteks komunikasi termediasi

$$
\text { Pendidikan }
$$


teknologi. Pemanfaatan teknologi yang praktis dan sederhana untuk menghasilkan materi belajar digital, materi pelatihan yang mudah dipahami, dan ketersediaan ruang diskusi selama proses pelatihan, memungkinkan peserta untuk dapat memahami setiap materi yang disampaikan.

\section{REFERENSI}

BAŞARMAK, U. (2019). The Effect Of Digital Teaching Material (Public Service Ad) Development Process On Preservice Teachers' Creative Thinking Skills. Malaysian Online Journal of Educational Technology, Volume 7, Issue 4. doi:http://dx.doi.org/10.17220/mojet.2019.0 4.009

Demirkan, Ö. (2019). Pre-service Teachers' Views about Digital Teaching Materials. Educational Policy Analysis and Strategic Research, V 14, N 1.

Fang, R.-J., Chang, C.-L., Tsai, H.-L., \& Jen-Lee, C. (2010). Explain the factors of primary school teachers choosing digitalized teaching materials with theory of planned behavior. Proceedings of the 10th WSEAS Int. Conference on MULTIMEDIA SYSTEMS \& SIGNAL PROCESSING.

Nuraini, R. (2020, Mret). Indonesia.go.id Portal Informasi Indonesia. Diambil kembali dari Indonesia.go.id:

https://indonesia.go.id/narasi/indonesia- dalam-angka/ekonomi/kasus-covid-19pertama-masyarakat-jangan-panik

Rosés, J. H., Anguelovski, I., Bohigas, J., Chireh, V., Daher, C., Konijnendijk, C., . . . Nieuwenhuijsen, M. (t.thn.). 1 The Impact of COVID-19 on Public Space: A Review of the Emerging Questions. Diambil kembali dari https://doi.org/10.31219/osf.io/rf7xa

Stiller, K. D., \& Bachmaier, R. (2017). Drop Out in an Online Traning for Trainee Teacher. European Journal of Open, Distance and eLearning , 20/No.1.

We are social. (2020, Januari). Diambil kembali dari wearesocial.com: https://wearesocial.com/digital-2020

Yang, L., Weng, T., Yang, D., \& Wu, P. (2014). The Effectiveness of Digital Teaching Materials on Introduction Statistics. International Conference on Education Reform and Modern Management (ERMM 2014). Dipetik June 15, 2020, dari https://www.researchgate.net/publication/26 6644271_The_Effectiveness_of_Digital_Te aching_Materials_on_Introduction_Statistic $\mathrm{s}$

Undang-Undang Republik Indonesia Nomor 39 tentang Hak Asasi Manusia. 1999. Indonesia. komnasham.go.id. 